\title{
PARTISIPASI ANGGOTA PADA KELOMPOK TANI KALELON DI DESA KAUNERAN, KECAMATAN SONDER, KABUPATEN MINAHASA
}

\author{
Richo Richardo Turangan \\ Theodora M. Katindagho \\ Benu Olfie L.S
}

\begin{abstract}
This study aims to determine the Members Participation in the Village Farmer Group Kalelon Kauneran District of Sonder Minahasa. The study lasted three months, the month of July 2016 until September 2016, ranging from preparation to preparation of research reports. The data used in this study are primary data and secondary data. The primary data obtained through interviews to respondents by using questionnaire and secondary data obtained through the office of the Village Kauneran. Data collection technique used census techniques are all members of the Farmers Group Kalelon of 20 people interviewed using a questionnaire. Analysis of the data in this study using the descriptive analysis and also using a Likert scale, with level 1 (underactive), 2 (active), 3 (highly active). The results showed, based on the Likert Scale, that the number of index Member Participation in Farmers Kalelon in the planning stage which also includes, liveliness and activeness followed meetings to provide input. Parisipasi members in the implementation phase also includes the activity, the activity of paddy rice cultivation, active in horticultural crop cultivation, active in post-harvest harvest to rice paddy, active in post-harvest harvest to horticultural crops, liveliness mengiktuti counseling, active in giving mandatory dues. Participation of members in the evaluation phase which include involvement in monitoring the group's activities, involvement in a variety of outcome measures farming activities. Participation of members of Kalelon farmer groups in the planning phase, the implementation phase and the evaluation phase were at 86, 5 is relatively high. Further analysis showed that the level of participation of members of the Farmer Group Kalelon on the score of 519 out of the range of the number of ideal scoring the highest score was 600 and the lowest score is 200. Suggestions in this research for members of farmer groups to improve their Kalelon activeness in following the extension because it are the main participants and entrepreneurs in the development of food security and the government should pay attention to what the needs of the farmer groups Kalelon for the development of farmer groups in general.
\end{abstract}

Keywords: Participation, Member, Farmers Group Kalelon, Kauneran Village, Sonder District, Minahasa

\begin{abstract}
ABSTRAK
Penelitian ini bertujuan untuk mengetahui Partisipasi Anggota pada Kelompok Tani Kalelon di Desa Kauneran. Kecamatan Sonder, Kabupaten Minahasa. Penelitian ini berlangsung selama 3 bulan, yaitu bulan Juli hingga September 2016. Data yang di gunakan dalam penelitian ini yaitu data primer dan data sekunder. Data primer diperoleh melalui wawancara langsung kepada responden dengan mengunakan kuesioner. Data sekunder diperoleh dari Kantor Desa Kauneran. Teknik pengumpulan data menggunakan teknik sensus yaitu semua anggota Kelompok Tani Kalelon berjumlah 20 orang di wawancarai. Analisis data dalam penelitian ini menggunakan analisis deskriptif dan juga menggunakan Skala Likert, dengan level 1 (kurang aktif), 2 (aktif), 3 (sangat aktif). Hasil penelitian menunjukan, berdasarkan Skala Likert, bahwa jumlah Indeks Partisipasi Anggota pada Kelompok Tani Kalelon pada tahap perencanaan mencakup, keaktifan mengikuti pertemuan dan keaktifan dalam memberikan masukan. Partisipasi anggota pada tahap pelaksanaan kegiatan mencakup keaktifan penanaman padi sawah, keaktifan dalam penanaman tanaman hortikultura, keaktifan dalam panen hingga pasca panen padi sawah, keaktifan dalam panen hingga pasca panen tanaman hortikultura, keaktifan mengikuti penyuluhan, keaktifan dalam memberikan iuran wajib. Partisipasi anggota pada tahap evaluasi mencakup keterlibatan dalam pemantauan kegiatan kelompok, keterlibatan dalam mengukur berbagai hasil kegiatan usaha tani. Partisipasi anggota pada tahap perencanaan, tahap pelaksanaan dan tahap evaluasi kelompok tani Kalelon berada pada 86, 5 yang tergolong tinggi. Analisis lebih lanjut menunjukkan bahwa tingkat partisipasi anggota pada Kelompok Tani Kalelon pada skor 519 dari kisaran jumlah yang ideal mencetak skor tertinggi adalah 600 dan skor terendah adalah 200. Dengan demikian anggota kelompok tani Kalelon perlu lebih meningkatkan keaktifan dalam mengikuti penyuluhan karena mereka merupakan pelaku utama dan pelaku usaha dalam pembangunan ketahanan pangan.
\end{abstract}

Kata Kunci: Partisipasi, Kelompok Tani Kalelon, Desa Kauneran, Kecamatan Sonder, Kabupaten Minahasa 


\section{PENDAHULUAN}

Sulawesi Utara memiliki tanah yang amat subur dan sangat kaya dengan hasil alamnya sehingga sangat cocok untuk bercocok tanam. Sumber Daya Manusia mempunyai peranan yang sangat penting dalam pembangunan. Sumber Daya Manusia yang memiliki jiwa sosial yang tinggi akan mampu meningkatkan produktivitas kelompok tani melalui partisipasi yang diberikan.Partisipasi memang bukanlah sesuatau yang baru yang kita lihat, dengar bahkan dilakukan dalam berbagai kegiatan yang bertujuan untuk membangun baik dari tingkat propinsi, kabupaten, kota, kelurahan maupun desa, suatu pembangunan dan pengembangan hasil pembangunan tidak akan berhasil tanpa adanya kinerja kelompok tani.

Partisipasi anggota atau partisipasi petani merupakan keikut sertaan dari petani baik secara individu maupun secara kelompok dengan penuh kesadaran dan tanggung jawab dalam bidang usaha pertanian. Partisipasi merupakan faktor yang sangat penting dalam malaksanakan berbagai aktivitas ataupun program pertanian. Partisipasi tersebut dapat berupa partisipasi dalam tahap pembentukan perencanaan, partisipasi dalam tahap pelaksanaan, dan partisipasi dalam tahap evaluasi.

Kelembagaan dalam pengertian ilmu sosial tidak semata-mata lembaga atau instansi atau organisasi yang memiliki struktur saja, namun juga meliputi seperangkat tatanan norma dalam kehidupan bermasyarakat guna mencapai tujuan tertentu Soekanto (2003) dalam Amanah dan Farmayanti (2014).

Pengertian kelembagaan juga mencakup kegiatan sistem gotong royong, sistem sakap dan bagi hasil, dan sebagainya, yang merupakan aktifitas kolektif masyarakat yang memiliki kelengkapan norma atau aturan tak tertulis yang dipahami dan disepakati oleh para pelakunya. Dalam uraian ini yang dimaksud dengan kelambagaan yang dibatasi sebagai suatu organisasi yang memiliki struktur. Sebagai contoh adalah kelompok tani yang secara structural memiliki kepengurusan berupa ketua, sekertaris, bendahara dan anggota, serta mamiliki atuaran-aturan keorganisasian. Nuryanti dan Swastika (2011), dijelaskan bahwa secara umum, kelompok tani dibentuk untuk memecahkan permasalahan yang dihadapi petani yang tidak bisa diatasi secara individu, kelompok tani dapat dibentuk secara swadaya maupun atas dasar kepentingan kebijakan dari pemerintah melalui Dinas Pertanian.

Kelompok Tani Kalelon merupakan salah satu kelompok tani yang aktif dari beberapa kelompok tani di Desa Kauneran Kalelon merupakan bahasa Tontemboan yang artinya 'dapa-dapa inga' atau 'sayang-sayang'. Kelompok tani Kelelon beranggotakan 20 orang dan di koordinir oleh ketua, kelompok dengan luas lahan padi sawah $15 \mathrm{Ha}$ dan luas lahan tanaman hortikultura sebesar 20 Ha. Kelompok Tani Kalelon terbentuk pada hari Sabtu tanggal 28 bulan Februari tahun 2009. Kelompok Tani Kalelon selalu aktif dalam kegiatan kelompoknya hal ini dikarenakan oleh budaya mapalus atau budaya gotong royong yang sangat tinggi yang ditanamkan oleh para anggota didalam kelompok. Ketua dari kelompok tani Kalelon merupakan petani yang mampu mengerakan seluruh anggotanya untuk selalu aktif dalam berbagai kegiatan yang dikarenakan oleh kelompok tani.

Kelompok Tani Kalelon adalah kelompok tani yang aktif di antara 8 kelompok tani yang ada di Desa Kauneran, karena rata-rata semua anggota Kelompok Tani Kalelon itu aktif dalam berbagai kegiatan kelompok tani. Kelompok Tani Kalelon menjadi kelompok tani yang teladan bagi kelompok-kelompok tani yang lain, karena Kelompok Tani Kalelon semua anggotanya dari berbagai hasil kegiatan kelompok tani dan juga Kelompok Tani Kalelon beberapa kali mendapat bantuan dari pemerintah yang dapat membantu anggota kelompok tani bahkan dapat membantu mensejahterakan masyarakat yang diberikan dari pemerintah.

Usaha meningkatkan kesejahteraan petani dan ketahanan pangan, peran kelembagaan kelompok tani dan partisipasi anggota sangat penting dalam mendukung dan melakasanakan berbagai program yang sedang dan akan dilaksansakan oleh kelompok tani. Hal inilah yang membuat penulis tertarik untuk mengangkat judul ini, serta penulis juga ingin mencari tahu bagaimana partisipasi anggota secara spesifik pada kelompok tani Kalelon karena hal tersebut merupakan pelaku utama dan pelaku usaha dalam pembangunan pangan. 


\section{Rumusan Masalah}

Berdasarkan uraian latar belakang yang dikemukakan, maka yang menjadi masalah dalam penelitian ini adalah bagaimana partisipasi anggota pada Kelompok Tani Kalelon.

\section{Tujuan Penelitian}

Penelitian ini bertujuan untuk mengetahui partisipasi anggota pada Kelompok Tani Kalelon.

\section{Manfaat Penelitian}

Memberikan informasi dan gambaran tentang partisipasi anggota pada Kelompok Tani Kalelon. Sebagai bahan pertimbangan bagi pemerintah dan instansi terkait untuk pengembangan kelompok tani pada umumnya.

\section{METODE PENELITIAN}

\section{Waktu dan Tempat Penelitian}

Penelitian ini dilaksanakan selama tiga bulan mulai dari Bulan Juli sampai dengan Bulan September 2016, mulai dari persiapan sampai dengan penyusunan laporan hasil penelitian. Tempat penelitian ini dilaksanakan pada Kelompok Tani Kalelon di Desa Kauneran, Kecamatan Sonder, Kabupaten Minahasa.

\section{Jenis dan Sumber Data}

Jenis dan sumber data dalam penelitian ini sebagai berikut:

1. Data primer diperoleh melalui wawancara langsung kepada responden dengan menggunakan kuesioner yang telah disiapkan.

2. Data sekunder diperoleh melalui Kantor Desa Kauneran.

\section{Teknik Pengumpulan Data}

Teknik yang digunakan dalam pengumpulan data adalah menggunakan teknis sensus yaitu semua anggota Kelompok Tani Kalelon berjumlah 20 orang merupakan responden, sehingga semua anggota diwawancarai dengan menggunakan kuesioner.

\section{Konsep Pengukur Variabel}

Variabel yang diukur dalam penelitian ini adalah:

1. Partisipasi dalam tahap pengambilan perencanaan yaitu seberapa aktif responden dalam mengikuti pertemuan dan keaktifan dalam memberikan masukan pada setiap pertemuan.

2. Partisipasi dalam tahap pelaksanaan yaitu seberapa aktif responden dalam mengikuti penanaman, panen dan pasca panen tanaman padi sawah dan tanaman hortikultura, keaktifan dalam mengikuti penyuluhan dan keaktifan dalam memberikan iuran wajib.

3. Partisipasi dalam tahap evaluasi yaitu keterlibatan dalam pemantauan kegiatan kelompok dan keterlibatan dalam mengukur berbagai hasil kegiatan usahatani.

\section{Indikator Partisipasi Responden}

a. Partisipasi dalam Tahap Pengambilan Perencanaan:

1. Keaktifan dalam mengikuti pertemuan

- Sangat Aktif (24 kali dalam setahun)

- Aktif (16 kali dalam setahun)

- Kurang Aktif (8 kali dalam setahun)

2. Keaktifan dalam memberikan masukan pada pertemuan

- Sangat Aktif (20 kali dalam setahun)

- Aktif (15 kali dalam setahun)

- Kurang Aktif (5 kali dalam setahun)

b. Partisipasi dalam Tahap Pelaksanaan:

1. Keaktifan dalam penanaman padi sawah

- Sangat Aktif (3 kali dalam setahun)

- Aktif (2 kali dalam setahun)

- Kurang Aktif ( - )

2. Keaktifan dalam penanaman hortikultura

- Sangat Aktif (4 kali penanaman dalam setahun)

- Aktif (2 kali penanaman dalam setahun)

- Kurang Aktif (1 kali penanaman dalam setahun)

3. Keaktifan dalam panen dan pasca panen padi sawah

- Sangat Aktif (3 kali dalam setahun)

- Aktif (2 kali dalam setahun)

- Kurang Aktif ( - )

4. Keaktifan dalam panen dan pasca panen tanaman hortikultura

- Sangat Aktif (6 kali panen dalam setahun)

- $\quad$ Aktif ( 4 kali panen dalam setahun) 
- Kurang Aktif (3 kali panen dalam setahun)

5. Keaktifan dalam mengikuti penyuluhan

- Sangat Aktif (24 kali dalam setahun)

- $\quad$ Aktif (18 kali dalam setahun)

- Kurang Aktif (12 kali dalam setahun)

6. Keaktifan dalam memberikan iuran wajib

- Sangat Aktif (25 kali dalam setahun)

- Aktif (20 kali dalam setahun)

- $\quad$ Kurang Aktif (15 kali dalam setahun)

\section{c. Partisipasi dalam Tahap Evaluasi}

1. Keterlibatan dalam pemantauan kegiatan kelompok

- Sangat Aktif (setiap hasil kegiatan kelompok selalu memberikan masukan dalam hasil yang diperoleh).

- Aktif (hampir disetiap kegiatan kelompok selalu memberikan).

- Kurang Aktif (jarang memperhatikan dan memberikan masukan mengenai kegiatan kelompok).

2. Keterlibatan dalam mengukur berbagai hasil kegiatan usahatani.

- Sangat Aktif (setiap hasil kegiatan usahatani selalu memberikan masukan dalam hasil yang diperoleh).

- Aktif (hampir disetiap kegiatan usahatani selalu memberikan).

- Kurang Aktif (jarang memperhatikan dan memberikan masukan

mengenai berbagai hasil kegiatan usahatani).

\section{Analisis Data}

Analisis data yang digunakan dalam penelitian ini adalah analisis deskriptif dengan mengunakan Skala Likert, Skala Likert digunakan untuk mengukur partisipasi seseorang atau kelompok dalam Skala Likert, maka variable yang diukur dijabarkan menjadi indicator variable. Kemudian indicator tersebut dijadikan sebagai titik tolak untuk menyusun item-item instrument yang dapat berupa pertanyaan-pertanyaan. Dalam penelitian ini disusun 10 (sepuluh) pertanyaan dengan total responden 20 (dua puluh) orang. Jawaban setiap instrument yang menggunakan skala likert diungkapkan dengan kata-kata, berikut:

\section{S3=Sangat Aktif \\ $\mathrm{S} 2=$ Aktif \\ S1=Kurang Aktif}

Dengan cara perhitungan skor masing-masing pertanyaan:

Jumlah skor tiap kriteria = capaian skor $\mathrm{x}$ jumlah responden.

$\mathrm{S} 3=3 \mathrm{X} 20=60$

$\mathrm{S} 2=2 \mathrm{X} 20=40$

$\mathrm{S} 1=1 \mathrm{X} 20=20$

Jumlah skor ideal untuk setiap pernyataan (skor tertinggi) $=60$

Jumlah skor terendah $=20$

Dengan interprestasi nilai:

$\begin{array}{llll}0 & 20 & 40 & 60\end{array}$

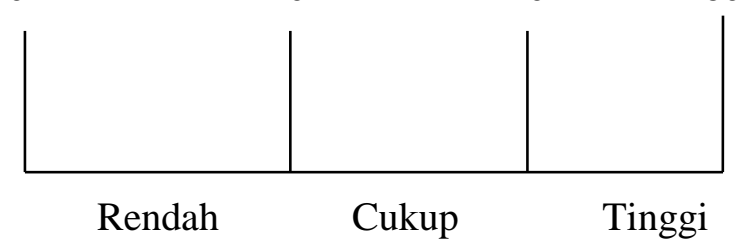

Cara perhitungan skor keseluruhan untuk mengetahui partisipasi anggota:

Jumlah skor seluruh kriterium = capaian jumlah $\mathrm{X}$ jumlah responden $\mathrm{X}$ instrument pertanyaan. Untuk :

$\mathrm{S} 3=3 \times 2 \mathrm{O} \times 10=600$

$\mathrm{S} 2=2 \times 20 \times 10=400$

$\mathrm{S} 1=1 \mathrm{X} 20 \times 10=200$

Jumlah skor ideal untuk keseluruhan pertnyaan $=600$ (tinggi) skor rendah $=200$ (rendah)

Jumlah

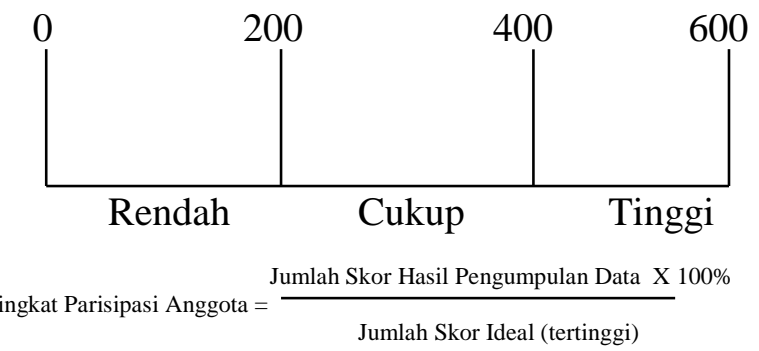

Dengan interprestasi nilai:

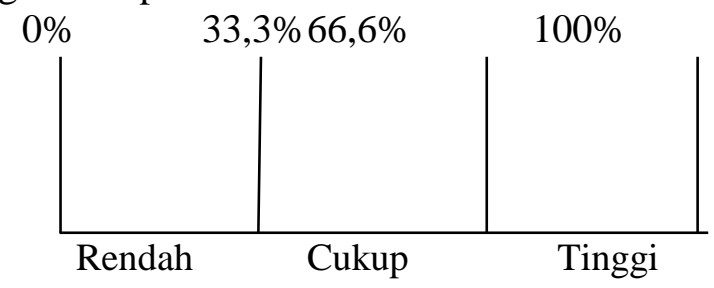




\section{HASIL DAN PEMBAHASAN}

\section{Deskripsi Wilayah Penelitian}

\section{Letak Geografis}

Desa Kauneran merupakan salah satu desa yang terletak di Kecamatan Sonder dengan luas wilayah 254 ha yang terdiri dari 4 (empat) jaga. Adapun batas-batas desa sebagai berikut:

1. Sebelah Utara : Desa Kauneran I

2. Sebelah Selatan : Desa Kiawa

3. Sebelah Barat

4. Sebelah Timur : Desa Tincep

\section{Keadaan Penduduk}

Total keseluruhan jumlah penduduk yang ada di Desa Kauneran sebanyak 1.459 jiwa. Tabel 1 menunjukkan jumlah penduduk yang ada di Desa Kauneran.

Tabel 1. Jumlah Penduduk Menurut Jenis Kelamin

\begin{tabular}{lccc}
\hline No. Jenis Kelamin & $\begin{array}{c}\text { Jumlah Penduduk } \\
\text { (Orang) }\end{array}$ & $(\%)$ \\
\hline 1. & Laki-laki & 760 & 52.00 \\
2. & Perempuan & 699 & 48.00 \\
\hline & Jumlah & $\mathbf{1 . 4 5 9}$ & $\mathbf{1 0 0}$ \\
\hline
\end{tabular}

Sumber: Kantor Desa Kauneran, 2015

Jumlah penduduk berjenis kelamin lakilaki sebanyak 760 atau 52.00 persen dan jumlah penduduk berjenis kelamin perempuan sebanyak 699 jiwa atau 48.00 persen, yang tersebar dalam 4 (empat) jaga dengan jumlah kepala keluarga sebanyak 329 kepala keluarga.

\section{Keadaan Sosial}

\section{a. Pendidikan}

Tingkat pendidikan di Desa Kauneran bervariasi mulai dari tamat Sekolah Dasar (SD) laki-laki 122 orang dan perempuan 131 orang, Sekolah Lanjutan Tingkat Pertama (SLTP) lakilaki 54 orang dan perempuan 63 orang, Sekolah Lanjutan Tingkat Atas (SLTA) laki-laki 82 orang dan perempuan 87 orang, tamat Diploma (D3) laki-laki 1 orang dan perempuan 3 orang, tamat perguruan tinggi yaitu mencakup tamat Strata Satu (Sl) laki-laki 12 orang dan perempuan 16 orang. tamat Magister (S2) laki-laki 2 orang dan perempuan 1 orang, tamat Doktor (S3) laki-laki 1 orang dan perempuan 1 orang.
Tabel 2. Jumlah Penduduk Berdasarkan Tingkat Pendidikan

\begin{tabular}{lccl}
\hline No. & Tingkat Pendidikan & Jumlah (Orang) & $(\%)$ \\
\hline 1. & Tamat SD & 253 & 43,92 \\
2. & SLTP & 117 & 20,31 \\
3. & SLTA & 169 & 29,34 \\
4. & Perguruan Tinggi & 37 & 6,42 \\
\hline & Jumlah & $\mathbf{5 7 6}$ & $\mathbf{1 0 0}$ \\
\hline
\end{tabular}

Sumber: Kantor Desa Kauneran, 2015

Tamat SD sebanyak 253 orang atau $43,92 \%$, SLTP Sebanyak 117 orang atau $20,31 \%$, SLTA sebanyak 169 orang atau $29,34 \%$, dan perguruan tinggi sebanyak 37 orang atau $6,42 \%$.

\section{Deskripsi Kelompok Tani Kalelon}

\section{Visi dan Misi Kelompok Tani Kalelon}

\section{a. Visi}

Untuk mensejahterakan Anggota.

\section{b. Misi}

Menjadikan Kelompok Tani Kalelon yang mandiri menuju kesejahteraan bersama.

\section{Sejarah Singkat terbentuknya Kelompok Tani Kalelon \\ Kelompok Tani Kalelon berdiri pada} tanggal 28 Februari 1997, terbentuknya Kelompok Tani Kalelon di motivasi karena sebagian besar petani pada waktu itu masih kekurangan ilmu bercocok tanam, sehingga kami membentuk kelompok tani untuk merangkul para petani agar bisa bercocok tanam dan saling berbagi ilmu tenang pertanian dan cara menggunakan teknologi pertanian agar bias meningkatkan hasil pertanian dan mampu mensejahterakan anggota kelompok tani. Kalelon merupakan bahasa daerah Minahasa lebih khusus bahasa Tontemboan dalam bahasa Manado Kalelon memiliki arti 'dapa-dapa inga' atau 'sayang-sayang' kemudian dibuatlah berita acara pembentukan kelompok tani kemudian pada bulan 28 Februari 2009 kelompok tani dikukuhkan oleh Pemerintah Kabupatan Minahasa, kelompok tani Kalelon sampai saat ini bukan hanya mengandalkan komoditi Padi sawah tetapi juga bercocok tanam tanaman hortikultura. 


\section{Karakteristik Responden}

\section{Umur Responden}

Kemampuan bekerja atau melakukan aktifitas secara fisik bahkan cara berpikir seseorang sangat dipengaruhi faktor umur. Demikian juga dengan para petani dalam melakukan pekerjaannya, anggota yang memiliki umur muda tentumya memiliki kondisi fisik yang lebih kuat serta memiliki daya berpikir yang lebih kreatif dibandingkan yang berumur tua. Dari data primer yang diperoleh, usia anggota antara 40 sampai 65 tahun. Komposisi umur responden dalam penelitian ini disajikan pada Tabel 3.

Tabel 3. Distribusi Responden menurut Umur Anggota Kelompok Tani Kalelon

\begin{tabular}{lccc}
\hline No & Umur & $\begin{array}{c}\text { Responden } \\
\text { (orang) }\end{array}$ & $(\%)$ \\
\hline 1. & $40-45$ & 5 & 25 \\
2. & $46-50$ & 7 & 35 \\
3. & $51-55$ & 4 & 20 \\
4. & $56-60$ & 2 & 10 \\
5. & $61-65$ & 2 & 10 \\
\hline & Jumlah & $\mathbf{2 0}$ & $\mathbf{1 0 0}$ \\
\hline
\end{tabular}

Sumber: Diolah dari data primer, 2016

Tabel 3 menunjukkan bahwa jumlah responden pada umur 40-45 tahun menunjukkan presentase yaitu sebanyak 5 responden $(25 \%)$, selanjutnya berada pada usia 46-50 tahun menunjukkan presentase sebanyak 7 responden (35\%), pada usia 51-55 tahun menunjukkan presentase sebanyak 4 responden (20\%), pada usia 56-60 tahun menunjukkan sebanyak 2 responden (10\%), usia 61-65 tahun menunjukkan sebanyak 2 responden $(10 \%)$.

\section{Jenis Kelamin Responden}

\section{Distibusi Responden Berdasarkan Jenis Kelamin Anggota Kelompok Tani Kalelon}

Menunjukkan bahwa jumlah responden semuanya hanya berjenis kelamin laki-laki dengan (20 orang) $100 \%$.

\section{Tingkat Pendidikan Responden}

Peranan pendidikan formal sangat penting dalam usaha peningkatan kualitas seseorang karena berguna dalam pembangunan pribadi serta peningkatan intelektual dan wawasan seseorang. Berdasarkan hasil penelitian, tingkat pendidik responden bervariasi mulai dari tingkat Sekolah Dasar
(SD), Sekolah Lanjutan Tingkat Pertama (SLTP) sampai Sekolah Lanjutan Tingkat Atas (SLTA). Komposisi tingkat pendidikan responden dalam penelitian ini dapat dilihat pada Tabel 4.

Tabel 4. Distribusi Responden menurut Tingkat Pendidikan anggota Kelompok Tani Kalelon

\begin{tabular}{cccc}
\hline No & Pendidikan & $\begin{array}{c}\text { Jumlah Responden } \\
\text { (Orang) }\end{array}$ & $(\%)$ \\
\hline 1 & SD & 7 & 35 \\
2 & SLTP & 5 & 25 \\
3 & SLTA & 8 & 40 \\
\hline & Jumlah & $\mathbf{2 0}$ & $\mathbf{1 0 0}$ \\
\hline
\end{tabular}

Sumber: Diolah dari data primer, 2016

Tabel 4 menunjukkan distribusi responden menurut tingkat pendidikan SD sebanyak 7 responden (35\%), SLTP sebanyak 5 responden $(25 \%)$, SLTA sebanyak 8 responden $(40 \%)$.

\section{Partisipasi Anggota pada Kelompok Tani Kalelon}

\section{Partisipasi Anggota pada Tahap Pengambilan Pelaksanaan}

Partisipasi pengambilan keputusan pada anggota kelompok tani Kalelon dengan mengadakan pertemuan yang dilaksanakan pada hari sabtu setiap 2 (dua) minggu sekali yang mengharuskan seluruh anggota kelompok tani hadir agar kesepakatan yang ingin dicapai dapat tercapai dengan pengambilan keputusan secara baik. Partisipasi dalam bentuk keaktifan anggota dalam mengikuti pertemuan sudah cukup baik, dengan melibatkan seluruh anggota dalam setiap kegiatan pengambilan keputusan. Perencanaan kegiatan yang biasanya dilakukan anggota yaitu merencanakan kegiatan penanaman padi sawah, mulai dari penanaman hingga panen dan pasca panen tidak hanya penanaman padi sawah tetapi juga penanaman tanaman hortikultura yaitu jagung dan cabe. Selain itu pengambilan keputusan dalam kelompok tani Kalelon juga dilakukan untuk mencari solusi dari berbagai masalah pertanian yang dihadapi dengan musyawarah yang dilakukan oleh seluruh anggota kelompok tani Kalelon. Dalam penelitian partisipasi pengambilan keputusan ini ada dua sub indikator yang diukur yaitu keaktifan anggota dalam mengikuti pertemuan dan keaktifan dalam memberikan masukan. 


\section{a. Keaktifan dalam mengikuti pertemuan}

Keaktifan dalam hal ini adalah seberapa sering anggota terlibat dalam mengikuti pertemuan kelompok yang dilaksanakan setiap hari sabtu. Dalam penelitian ini keaktifan dalam mengikuti pertemuan di ukur selama setahun dimana pertemuan membahas mengenai berbagai kegiatan kelompok tani dimana anggota harus melaksanakan penanaman padi sawah dan penanaman tanaman hortikultura, pelaksanaan penanaman secara mapalus atau gotong royong Seluruh anggota bertanggung jawab dalam pelaksanaannya mulai dari persiapan lahan, perawatan tanaman sampai dengan panen hingga pasca panen padi sawah dan tanaman hortikultura. Keaktifan dalam mengikuti pertemuan dapat dilihat pada Tabel 5.

Hasil penelitian ini menunjukkan bahwa $50 \%$ responden (10 orang) memilih sangat aktif anggota yang memilih sangat aktif adalah anggota yang sadar akan statusnya sebagai pengurus kelompok, anggota yang menginginkan terciptanya kekompakkan sesama anggota kelompok dalam melaksanakan kegiatan pertanian, 35\% responden (7 orang) memilih aktif adalah anggota yang mengikuti pertemuan agar memahami dan mengetahui halhal yang harus dilakukan dalam penanaman padi sawah dan penanaman tanaman hortikultura, $15 \%$ responden (3 orang) memilih kurang aktif dalam mengikuti pertemuan hal ini dikarenakan berbagai kesibukan. Total skor yang diperoleh dari 20 responden pada pertanyaan nomor 1 adalah 47. Angka indeks partisipasi mengenai pertanyaan nomor 1 yaitu:
$47 / 60 \times 100=78.33 \%$ sehingga interpretasi nilainya tergolong tinggi. Karena banyak anggota yang terlibat dalam mengikuti pertemuan setiap hari sabtu.

\section{b. Keaktifan dalam Memberikan Masukan}

Keaktifan dalam hal ini adalah seberapa sering anggota terlibat dalam memberikan masukan pada pertemuan yang dilaksanakan setiap hari sabtu. Dalam penelitian tentang keaktifan dalam memberikan masukan di ukur selama setahun,keaktifan dalam memberikan masukan dapat dilihat pada Tabel 6.

Hasil penelitian ini menunjukkan bahwa $45 \%$ responden ( 9 orang) memilih sangat aktif; anggota yang memilih sangat aktif adalah anggota yang sangat aktif memberikan masukan dalam bentuk pengurusan kelompok, memberi saran dalam hal kehadiran pertemuan kelompok dan saran untuk perkembangan kelompok, $40 \%$ respoden ( 8 orang) memilih aktif, anggota yang memilih aktif adalah anggota yang memberikan masukan tentang keaktifan anggota dalam kegiatan-kegiatan kelompok, 15\% responden (3 orang) memilih kurang aktif hal ini dikarenakan anggota kurang berpengalaman. Total skor yang diperoleh dari 20 responden pada pertanyaan nomor 2 adalah 46. Angka indeks partisipasi mengenai pertanyaan nomor 2 yaitu: $46 / 60 \mathrm{x}$ $100=76,66 \%$ sehingga interpretasi nilainya tergolong tinggi. Karena pada saat pertemuan banyak anggota yang sangat aktif dan aktif dalam memberikan masukan.

Tabel 5. Keaktifan dalam Mengikuti Pertemuan

\begin{tabular}{lccccc}
\hline No & $\begin{array}{c}\text { Tingkat } \\
\text { Partisipasi }\end{array}$ & $\begin{array}{c}\text { Alternatife } \\
\text { Skor }\end{array}$ & $\begin{array}{c}\text { Jumlah Responden } \\
\text { (Orang) }\end{array}$ & $\begin{array}{c}\text { Total } \\
\text { Skor }\end{array}$ \\
\hline 1 & Sangat Aktif & 3 & 10 & 50 & 30 \\
2 & Aktif & 2 & 7 & 35 & 14 \\
3 & Kurang Aktif & 1 & 3 & 15 & 3 \\
\hline & Jumlah & & $\mathbf{2 0}$ & $\mathbf{1 0 0}$ & $\mathbf{4 7}$ \\
\hline
\end{tabular}

Sumber. Diolah dari Data Primer, 2016 
Tabel 6. Keaktifan dalam memberikan masukkan

\begin{tabular}{|c|c|c|c|c|c|}
\hline No & $\begin{array}{l}\text { Tingkat } \\
\text { Partisiasi }\end{array}$ & $\begin{array}{l}\text { Alternatife } \\
\text { Skor }\end{array}$ & $\begin{array}{l}\text { Jumlah Responden } \\
\text { (Orang) }\end{array}$ & $\begin{array}{c}\text { Persentase } \\
(\%)\end{array}$ & $\begin{array}{l}\text { Total } \\
\text { Skor }\end{array}$ \\
\hline 1 & Sangat Aktif & 3 & 9 & 45 & 27 \\
\hline 2 & Aktif & 2 & 8 & 40 & 16 \\
\hline 3 & Kurang Aktif & 1 & 3 & 15 & 3 \\
\hline & Jumlah & & 20 & 100 & 46 \\
\hline
\end{tabular}

Sumber: Diolah dari Data Primer, 2016

\section{Partisipasi Anggota pada Pelaksanaan Kegiatan Kelompok}

Partisipasi pelaksanaan kegiatan kelompok tani Kalelon selalu diikuti oleh anggota kelompok tani Kalelon dengan aktif. Kegiatan kelompok tani Kalelon yang dilaksankan secara umum yaitu kegiatan penanaman padi sawah yang dilaksanakan selama 1 sampai 2 kali musim penanaman dalam setahun, penanaman tanaman hortikultura yang dilakukan 1 sampai 4 kali penanaman selama setahun, begitu juga dengan kegiatan panen dan pasca panen padi sawah yang dilaksanakan selama 1 sampai 2 kali dalam setahun, kegiatan panen dan pasca panen tanaman hortikultura yang dilaksanakan 3 sampai 6 Kali dalam setahun untuk jagung 3 kali panen dalam setahun dan cabe 3 kali panen dalam setahun dan untuk cabe dalam waktu pemanenannya itu dilakukan secara bertahap, kegiatan penyuluhan yang didampingi oleh Penyuluh Pertanian Lapangan yang selama setahun 12 sampai 24 kali dilaksanakan penyuluhan dalam setahun, kegiatan dalam memberikan iuran wajib yang pengumpulannya di lakukan 15 sampai 25 kali dalam setahun. Dalam penelitian partisipasi dalam tahap pelaksanaan ada 6 bagian yang di ukur yaitu, keaktifan dalam kegiatan penanaman padi sawah, keaktifan dalam penanaman tanaman hortikultura, keaktifan dalam panen dan pasca panen padi sawah, keaktifan dalam panen dan pasca panen tanaman hortikultura, keaktifan dalam mengikuti penyuluhan, dan keaktifan dalam memberikan iuran wajib.

\section{a. Keaktifan dalam Kegiatan Penanaman Padi Sawah}

Keaktifan dalam kegiatan penanaman padi sawah adalah seberapa sering anggota terlibat dalam tahap penanaman, dalam hal ini bukan hanya penanaman tetapi juga terlibat dalam pemeliharaan padi sawah, dalam penelitian ini keaktifan di ukur selama 2 musim penanaman dalam setahun, keaktifan dalam kegiatan penanaman padi sawah dapat dilihat pada Tabel 7.

Hasil penelitian ini menunjukkan bahwa $60 \%$ responden (12 orang) memilih sangat aktif adalah anggota yang ingin meningkatkan pendapatan, $40 \%$ responden ( 8 orang) memilih aktif adalah anggota yang berpengalaman dalam bertani. Total skor yang diperoleh dari 20 responden pada pertanyaan ini adalah 52. Angka indeks partisipasi mengenai pertanyaan nomor 3 yaitu: $52 / 60$ x $100=86,66 \%$ sehingga interpretasi nilainya tergolong tinggi.Karena anggota sangat aktif dalam kegiatan penanaman padi sawah.

\section{b. Keaktifan dalam penanaman tanaman hortikultura}

Keaktifan dalam kegiatan penanaman tanaman hortikultura adalah seberapa sering anggota terlibat dalam penanaman tanaman hortikultura bukan hanya penanaman saja tetapi juga terlibat dalam merawat tanaman sampai dengan panen hingga pasca panen, tanaman hortikultura yang ditanaman adalah jagung dan cabe dalam penelitian ini keaktifan di ukur sebanyak 2 sampai 4 kali penanaman dalam setahun, keaktifan dalam penanaman tanaman hortikultura dapat dilihat pada Tabel 8 .

Hasil penelitian ini menunjukkan bahwa $75 \%$ responden (15 orang) memilih sangat aktif adalah anggota yang ingin meningkatkan pendapatan, $15 \%$ responden ( 3 orang) memilih aktif, $10 \%$ responden ( 2 orang) memilih kurang aktif adalah mereka yang memiliki berbagai kesibukan. Total skor yang diperoleh dari 20 responden pada pertanyaan nomor 4 adalah 53 . Angka indeks partisipasi mengenai pertanyaan nomor 4 yaitu: $53 / 60$ x $100=88,33 \%$ sehingga interpretasi nilainya tergolong tinggi. 


\section{c. Keaktifan dalam Panen hingga Pasca Panen Padi Sawah}

Keaktifan dalam panen hingga pasca panen padi sawah adalah seberapa sering anggota terlibat dalam tahap panen hingga pasca panen padi sawah, pelaksanaan kegiatan panen hingga pasca panen padi sawah dalam penelitian ini di ukur sebanyak 1 sampai 2 kali pemanenan selama setahun untuk padi sawah yang sudah di panen dari lahan setiap anggota kemudian disisihkan $10 \%$ hasil padi sawah dari tiap-tiap anggota untuk dipasarkan. Keaktifan dalam panen dan pasca panen padi sawah dapat dilihat pada Tabel 9.

Hasil penelitian ini menunjukkan bahwa $85 \%$ responden (17 orang) memilih sangat aktif adalah anggota yang bersemangat dalam kegiatan pemanenan dan memiliki kesadaran sebagai pengurus kelompok, $15 \%$ responden (3 orang) memilih aktif adalah anggota yang ingin melancarkan kegiatan pertanian. Total skor yang diperoleh dari 20 responden pada pertanyaan nomor 5 adalah 57. Angka indeks partisipasi mengenai pertanyaan nomor 5 yaitu: $57 / 60 \times 100=95 \%$ sehingga interpretasi nilainya tergolong tinggi. Karena anggota sangat aktif setiap panen hingga pasca partai padi sawah.

\section{d. Keaktifan dalam Panen hingga Pasca Panen Tanaman Hortikultura.}

Keaktifan dalam hal ini ada adalah seberapa sering anggota terlibat dalam kegiatan panen hingga pasca panen tanaman hortikultura yaitu jagung dan cabe yang nantinya setelah pasca panen dijual langsung ke pasar dalam penelitian ini keaktifan dalam panen dan pasca panen di ukur sebanyak 3 sampai 6 kali pemanenan dalam setahun. Keaktifan dalam panen dan pasca panen tanaman hortikultura dapat dilihat pada Tabel 10.

Hasil penelitian ini menunjukkan bahwa $80 \%$ responden (16 orang) memilih sangat aktif adalah anggota yang ingin menambah penghasilan, memperlancar kegiatan kelompok, $15 \%$ responden (3 orang) memilih aktif; 5\% responden (1 orang) memilih kurang aktif karena berbagai kesibukan lainnya. Total skor yang diperoleh dari 20 responden pada pertanyaan no 6 adalah 55. Angka indeks partisipasi mengenai pertanyaan nomor 6 yaitu: $55 / 60 \times 100=91,66$ sehingga interpretasi nilainya tergolong tinggi. Karena pada saat panen hingga pasca panen tanaman hortikultura anggota sangat aktif dalam pelaksanaannya tergolong tinggi. Karena anggota sangat aktif setiap panen hingga pasca panen padi sawah.

\section{e. Keaktifan dalam Mengikuti Penyuluhan}

Keaktifan dalam hal ini adalah seberapa sering anggota terlibat dalam mengikuti penyuluhan mengenai penyuluhan penanaman padi sawah dan tanaman hortikultura, penyuluhan merawat tanaman padi sawah dan tanaman hortikultura, penyuluhan panen hingga pasca panen padi sawah dan tanaman hortikultura, setiap bulannya anggota mengikuti penyuluhan yang didampingi oleh Penyuluh Pertanian Lapangan (PPL) Desa Kauneran dalam sebulan penyuluhan dilaksanakan 2 kali, dalam penelitian ini keaktifan dalam mengikuti penyuluhan yang didampingi oleh PPL di ukur selama setahun. Keaktifan dalam mengikuti penyuluhan dapat dilihat pada Tabel 11 .

Hasil penelitian ini menunjukkan bahwa $40 \%$ Responden (8 orang) memilih sangat aktif adalah anggota yang selalu hadir pada saat dilaksanakan penyuluhan dan anggota mengikuti penyuluhan agar dapat mengetahui apa saja yang akan dilakukan dalam kegiatan usahatani, 35\% Responden (7 orang) memilih aktif adalah anggota yang mengikuti penyuluhan untuk menunjang berbagai kegiatan kelompok tani, 25\% Responden (5 orang) memilih kurang aktif adalah anggota yang jarang hadir dalam penyuluhan dikarenakan oleh berbagai kesibukan. Total skor yang diperoleh dari 20 Responden pada pertanyaan no 7 adalah 43. Angka indeks partisipasi mengenai pertanyaan nomor 7 yaitu: $43 / 60 \mathrm{x}$ $100=71.66 \%$ sehingga interpretasi nilainya tergolong tinggi. Karena pada saat penyuluhan hampir semua anggota terlibat dalam kegiatan penyuluhan.

\section{f. Keaktifan dalam Memberikan Iuran Wajib}

Keaktifan dalam hal ini adalah seberapa sering anggota memberikan iuran wajib sebesar Rp3.000 hingga Rp10.000 yang dikumpul sekali dalam seminggu, yang dipakai untuk berbagai kegiatan kelompok seperti pembelian pupuk, racun untuk tanaman bahkan digunakan untuk natal kelompok tani dalam penelitian ini keaktifan diukur selama setahun, keaktifan dalam memberikan iuran wajib dapat dilihat pada Tabel 12. 
Hasil penelitian ini menunjukkan bahwa $85 \%$ responden (17 orang) memilih sangat aktif adalah anggota yang sadar akan kewajibannya dimana mengumpulkan iuran merupakan keharusan yang telah disepakati bersama dan iuran akan digunakan untuk kesejahteraan kelompok, $10 \%$ responden ( 2 orang) memilih aktif anggota yang mengumpulkan iuran untuk menunjang kegiatan kelompok tani, 5\% responden (1 orang) memilih kurang aktif adalah anggota yang sibuk dengan berbagai kesibukan lainnya sehingga. Total skor yang diperoleh dari 20 Responden pada pertanyaan no 8 adalah 56. Angka indeks partisipasi mengenai pertanyaan nomor 8 yaitu: 56/60 x $100=93,33 \%$ sehingga interpretasi nilainya tergolong tinggi. Karena dalam mengumpulkan iuran wajib anggota sangat aktif dalam memberi.

Tabel 7. Keaktifan dalam Kegiatan Penanaman Padi Sawah

\begin{tabular}{cccccc}
\hline No & $\begin{array}{c}\text { Tingkat } \\
\text { Partisipasi }\end{array}$ & $\begin{array}{c}\text { Alternatife } \\
\text { Skor }\end{array}$ & $\begin{array}{c}\text { Jumlah Responden } \\
\text { (Orang) }\end{array}$ & $(\%)$ & $\begin{array}{c}\text { Total } \\
\text { Skor }\end{array}$ \\
\hline 1 & Sangat Aktif & 3 & 12 & 60 & 36 \\
2 & Aktif & 2 & 8 & 40 & 16 \\
3 & Kurang Aktif & 1 & - & - & - \\
\hline & Jumlah & & $\mathbf{2 0}$ & $\mathbf{1 0 0} \mathbf{5 2}$ & \\
\hline
\end{tabular}

Sumber: Diolah dari Data Primer, 2016

Tabel 8. Keaktifan dalam Penanaman Tanaman Hortikultura

\begin{tabular}{cccccc}
\hline No & $\begin{array}{c}\text { Tingkat } \\
\text { Partisipasi }\end{array}$ & $\begin{array}{c}\text { Alternatife } \\
\text { Skor }\end{array}$ & $\begin{array}{c}\text { Jumlah Responden } \\
\text { (Orang) }\end{array}$ & $(\%)$ & $\begin{array}{c}\text { Total } \\
\text { Skor }\end{array}$ \\
\hline 1 & Sangat Aktif & 3 & 15 & 75 & 45 \\
2 & Aktif & 2 & 3 & 15 & 6 \\
3 & Kurang Aktif & 1 & 2 & 10 & 2 \\
\hline Jumlah & & $\mathbf{2 0}$ & $\mathbf{1 0 0}$ & $\mathbf{5 3}$ \\
\hline
\end{tabular}

Sumber: Diolah dari Data Primer, 2016

Tabel 9. Keaktifan dalam Panen hingga Pasca Panen Padi Sawah

\begin{tabular}{cccccc}
\hline No & $\begin{array}{c}\text { Tingkat } \\
\text { Partisipasi }\end{array}$ & $\begin{array}{c}\text { Alternatife } \\
\text { Skor }\end{array}$ & $\begin{array}{c}\text { Jumlah Responden } \\
\text { (Orang) }\end{array}$ & $(\%)$ & $\begin{array}{c}\text { Total } \\
\text { Skor }\end{array}$ \\
\hline 1 & Sangat Aktif & 3 & 17 & 85 & 51 \\
2 & Aktif & 2 & 3 & 15 & 6 \\
3 & Kurang Aktif & 1 & - & - & - \\
\hline Jumlah & & $\mathbf{2 0}$ & $\mathbf{1 0 0}$ & $\mathbf{5 7}$ \\
\hline
\end{tabular}

Sumber: Diolah dari Data Primer, 2016 
Tabel 10. Keaktifan dalam Panen dan Pasca Panen Tanaman Hortikultura

\begin{tabular}{cccccc}
\hline No & $\begin{array}{c}\text { Tingkat } \\
\text { Partisipasi }\end{array}$ & $\begin{array}{c}\text { Alternatife } \\
\text { Skor }\end{array}$ & $\begin{array}{c}\text { Jumlah Responden } \\
\text { (Orang) }\end{array}$ & $(\%)$ & $\begin{array}{c}\text { Total } \\
\text { Skor }\end{array}$ \\
\hline 1 & Sangat Aktif & 3 & 16 & 80 & 48 \\
2 & Aktif & 2 & 3 & 15 & 6 \\
3 & Kurang Aktif & 1 & 1 & 5 & 1 \\
\hline & Jumlah & & $\mathbf{2 0}$ & $\mathbf{1 0 0}$ & $\mathbf{5 5}$ \\
\hline
\end{tabular}

Sumber: Diolah dari Data Primer, 2016

Tabel 11. Keaktifan dalam Mengikuti Penyuluhan

\begin{tabular}{cccccc}
\hline No & $\begin{array}{c}\text { Tingkat } \\
\text { Partisipasi }\end{array}$ & $\begin{array}{c}\text { Alternatife } \\
\text { Skor }\end{array}$ & $\begin{array}{c}\text { Jumlah Responden } \\
\text { (Orang) }\end{array}$ & $(\%)$ & $\begin{array}{c}\text { Total } \\
\text { Skor }\end{array}$ \\
\hline 1 & Sangat Aktif & 3 & 8 & 40 & 24 \\
2 & Aktif & 2 & 7 & 35 & 14 \\
3 & Kurang Aktif & 1 & 5 & 25 & 5 \\
\hline & Jumlah & & $\mathbf{2 0}$ & $\mathbf{1 0 0}$ & $\mathbf{4 3}$ \\
\hline
\end{tabular}

Sumber: Diolah dari Data Primer, 2016

Tabel 12. Keaktifan dalam Memberikan luran Wajib

\begin{tabular}{cccccc}
\hline No & $\begin{array}{c}\text { Tingkat } \\
\text { Partisipasi }\end{array}$ & $\begin{array}{c}\text { Alternatife } \\
\text { Skor }\end{array}$ & $\begin{array}{c}\text { Jumlah Responden } \\
\text { (Orang) }\end{array}$ & $(\%)$ & $\begin{array}{c}\text { Total } \\
\text { Skor }\end{array}$ \\
\hline 1 & Sangat Aktif & 3 & 17 & 85 & 51 \\
2 & Aktif & 2 & 2 & 10 & 4 \\
3 & Kurang Aktif & 1 & 1 & 5 & 1 \\
\hline & Jumlah & & $\mathbf{2 0}$ & $\mathbf{1 0 0}$ & $\mathbf{5 6}$ \\
\hline
\end{tabular}

Sumber: Diolah dari Data Primer, 2016

\section{Partisipasi Anggota Pada Tahap Evaluasi Kegiatan dalam Kelompok Tani Kalelon}

Partisipasi evaluasi kegiatan kelompok tani Kalelon yaitu memantau kegiatan kelompok dan mengukur berbagai hasil kegiatan usaha tani yang telah dilakukan. Evaluasi yang dilakukan yaitu bermusyawarah mengenai berbagai kekurangan. Selain itu kelompok tani Kalelon juga berusaha meningkatkan kualitas usaha tani yang dilaksanakannya. Dalam penelitian partisipasi dalam tahap evaluasi ada 2 bagian yang diukur yaitu, keterlibatan dalam pemantauan kegiatan kelompok dan keterlibatan dalam mengukur berbagai hasil kegiatan usaha tani.

\section{a. Keterlibatan dalam Pemantauan Kegiatan Kelompok}

Keterlibatan dalam hal ini adalah seberapa sering anggota terlibat dalam tahap pemantauan kegiatan kelompok, dalam hal ini bukan hanya sekedar memantau tetapi juga berperan aktif dalam berbagai kegiatan kelompok, keterlibatan dalam pemantauan kegiatan kelompok dalam penelitian ini diukur dalam setahun, dapat dilihat pada Tabel 13 .

Hasil penelitian ini menunjukkan bahwa $80 \%$ responden (16 orang) memilih sangat aktif adalah anggota yang memiliki tugas sebagai pengurus kelompok dan selalu terlibat dalam memberikan masukan dalam memantau kegiatan kelompok untuk kesejahteraan anggota 
dalam meningkatkan hasil panen serta pendapatan anggota, 10\% responden ( 2 orang) memilih aktif adalah anggota yang berpengalaman dalam memberikan masukan, $10 \%$ responden ( 2 orang) memilih kurang aktif adalah anggota yang kurang berpengalaman dalam pemantauan kegiatan kelompok. Total skor yang diperoleh dari 20 Responden pada pertanyaan no 9 adalah 54. Angka indeks partisipasi mengenai pertanyaan nomor 9 yaitu: $54 / 60 \times 100=90 \%$ sehingga interpretasi nilainya tergolong tinggi. Karena anggota sangat aktif dalam memantau kegiatan kelompok.

\section{b. Keterlibatan dalam Mengukur Berbagai Hasil Kegiatan Usaha Tani}

Keterlibatan dalam hal ini adalah seberapa sering anggota terlibat dalam tahap mengukur berbagai hasil kegiatan usaha tani dalam hal ini bukan saja mengukur tetapi juga berperan aktif dalam pemanfaatan berbagai hasil kegiatan usaha tani untuk kebutuhan hidup sehari-hari. Keterlibatan dalam mengukur berbagai hasil kegiatan usaha tani dapat dilihat pada Tabel 14.

Hasil penelitian ini menunjukkan bahwa $75 \%$ responden (17 orang) memilih sangat aktif adalah anggota yang ingin mengetahui apa saja yang dicapai dalam usaha tani dan terlibat dalam memberikan masukan karena merupakan petani berpengalaman, $10 \%$ responden (2 orang) memilih aktif adalah anggota yang berpengalaman dalam memberikan masukan dalam kegiatan usaha tani, 5\% (1 orang) memilih kurang aktif adalah anggota yang kurang berpengalaman dalam kegiatan usaha tani dan memiliki berbagai kesibukan lainnya.

Total skor yang diperoleh dari 20 Responden pada pertanyaan no 10 adalah 56. Angka indeks partisipasi mengenai pertanyaan nomor 10 yaitu: 56/60x $100=93,33 \%$ sehingga interpretasi nilainya tergolong tinggi. Karena anggota sangat aktif dalam mengukur berbagai hasil kegiatan usaha tani.

Tabel 13. Keterlibatan dalam Pemantauan Kegiatan Kelompok

\begin{tabular}{|c|c|c|c|c|c|}
\hline No & $\begin{array}{c}\text { Tingkat } \\
\text { Partisipasi }\end{array}$ & $\begin{array}{l}\text { Alternatife } \\
\text { Skor }\end{array}$ & $\begin{array}{l}\text { Jumlah Responden } \\
\text { (Orang) }\end{array}$ & $(\%)$ & $\begin{array}{l}\text { Total } \\
\text { Skor }\end{array}$ \\
\hline 1 & Sangat Aktif & 3 & 16 & 80 & 48 \\
\hline 2 & Aktif & 2 & 2 & 10 & 4 \\
\hline 3 & Kurang Aktif & 1 & 2 & 10 & 2 \\
\hline \multicolumn{3}{|c|}{ Jumlah } & 20 & 100 & 54 \\
\hline
\end{tabular}

Sumber: Diolah dari Data Primer, 2016

Tabel 14. Keterlibatan dalam Mengukur Berbagai Hasil Kegiatan Usaha Tani

\begin{tabular}{rlrccc}
\hline No & $\begin{array}{c}\text { Tingkat } \\
\text { Partisipasi }\end{array}$ & \multicolumn{2}{c}{$\begin{array}{c}\text { Alternatife } \\
\text { Skor }\end{array}$} & $\begin{array}{c}\text { Jumlah Responden } \\
\text { (Orang) }\end{array}$ & \multicolumn{2}{c}{ Total } \\
1 & Sangat Aktif & 3 & 17 & 85 & 51 \\
2 & Aktif & 2 & 2 & 10 & 4 \\
3 & Kurang Aktif & 1 & 1 & 5 & 1 \\
\hline Jumlah & & $\mathbf{2 0}$ & $\mathbf{1 0 0}$ & $\mathbf{5 6}$ \\
\hline
\end{tabular}

Sumber: Diolah dari Data Primer, 2016 


\section{Rekapitulasi Indikator Partisipasi Anggota pada Kelompok Tani Kalelon}

Tabel 15. Rekapitulasi Partisipasi Anggota Pada Kelompok Tani Kalelon

\begin{tabular}{|c|c|c|c|c|}
\hline No & Pertanyaan & $\begin{array}{l}\text { Total } \\
\text { Skor }\end{array}$ & $\begin{array}{c}\text { Indeks } \\
\text { Partisipasi }\end{array}$ & Interpretasi \\
\hline 1 & Keaktifan dalam mengikuti pertemuan & 47 & 78,3 & Tinggi \\
\hline 2 & Keaktifan dalam memberikan masukkan & 46 & 76,6 & Tinggi \\
\hline 3 & $\begin{array}{l}\text { Keaktifan dalam kegiatan penanaman } \\
\text { padi sawah }\end{array}$ & 52 & 86,6 & Tinggi \\
\hline 4 & $\begin{array}{l}\text { Keaktifan dalam kegiatan penanaman } \\
\text { Tanaman hortikultura }\end{array}$ & 53 & 88,3 & Tinggi \\
\hline 5 & $\begin{array}{l}\text { Keaktifan panen dan pasca panen } \\
\text { padi sawah }\end{array}$ & 57 & 95 & Tinggi \\
\hline 6 & $\begin{array}{l}\text { Keaktifan dalam panen dan pasca } \\
\text { panen tanaman hortikultura }\end{array}$ & 55 & 91,6 & Tinggi \\
\hline 7 & Keaktifan dalam mengikuti penyuluhan & 43 & 71,6 & Tinggi \\
\hline 8 & Keaktifan dalam memberikan iuran wajib & 56 & 93,3 & Tinggi \\
\hline 9 & $\begin{array}{l}\text { Keterlibatan dalam pemantauan } \\
\text { kegiatan kelompok }\end{array}$ & 54 & 90 & Tinggi \\
\hline 10 & $\begin{array}{l}\text { Keterlibatan dalam mengukur berbagai } \\
\text { hasil kegiatan usaha tani }\end{array}$ & 56 & 93,3 & Tinggi \\
\hline & Total & 519 & & \\
\hline
\end{tabular}

Sumber : Diolah dari Data Primer, 2016

Tabel 15 menunjukkan bahwa terdapat 10 indikator partisipasi anggota pada kelompok tani Kalelon dimana pertanyaan ke 5 mendapat indeks tertinggi yaitu 95\%, karena anggota kelompok tani Kalelon sangat aktif pada setiap panen dan pasca panen padi sawah. Sedangkan pertanyaan 1 mendapat indeks partisipasi $78,3 \%$, pertanyaan 2 mendapat indeks partisipasi $76,6 \%$, pertanyaan 3 mendapat indeks partisipasi $86,6 \%$, pertanyaan ke 4 mendapat indeks partisipasi $88,3 \%$, pertanyaan ke 5 mendapat indeks partisipasi $95 \%$, pertanyaan ke 6 mendapat indeks partisipasi 91,6\%, pertanyaan ke 7 mendapat indeks partisipasi $71,6 \%$, pertanyaan ke 8 mendapat indeks partisipasi $93,3 \%$, pertanyaan ke 9 mendapat indeks partisipasi $90 \%$, pertanyaan ke 10 mendapat indeks partisipasi $93,3 \%$ hampir semuanya mendapat interpretasi tinggi. Pertanyaan ke 7 mendapat interpretasi cukup karena berada di $71,6 \%$. Dan pertanyaan $1,2,3,4,5,6,8,9,10$ mendapat interpretasi tinggi karena berada di atas $71,6 \%$. Untuk mengetahui partisipasi anggota pada kelompok tani Kalelon di Desa Kauneran maka perlu di hitung jumlah keseluruhan skor. Dimana hasil penelitian ini skor mencapai 515. Pada penelitian ini jumlah skor ideal atau skor tertinggi yaitu 600 dan jumlah skor terendah adalah 200 .
Dari data yang dihimpun sebanyak 10 pertanyaan yang diajukan kepada 20 responden maka diperoleh total skor 515. Secara \% angka indeks partisipasi anggota pada kelompok tani Kalelon di Desa Kauneran Kecamatan Sonder terletak pada :

$$
\begin{aligned}
\text { Tingkat Partisipasi } & =\frac{519}{600} \times 100 \% \\
& =86,5 \%
\end{aligned}
$$

Berdasarkan hasil analisis menggunakan skala likert maka dapat diketahui bahwa angka indeks partisipasi anggota pada kelompok tani Kalelon berada pada titik $86.5 \%$ dan tergolong tinggi. Kesimpulan secara keseluruhan dari penelitian ini tergambar dalam rekapitulasi jumlah skor partisipasi anggota pada kelompok tani Kalelon. Partisipasi pada kegiatan lainnya semuanya tergolong tinggi. Kecuali keaktifan dalam mengikuti penyuluhan yang tergolong cukup.

\section{KESIMPULAN DAN SARAN}

\section{Kesimpulan}

Berdasarkan hasil penelitian diketahui bahwa partisipasi anggota pada tahap perencanaan, tahap pelaksanaan dan tahap evaluasi kelompok tani Kalelon tergolong tinggi. 


\section{Saran}

Bagi Anggota kelompok tani Kalelon agar lebih meningkatkan keaktifan dalam mengikuti penyuluhan karena hal tersebut merupakan pelaku utama dan pelaku usaha dalam pembangunan ketahanan pangan dan pemerintah hendaknya memperhatikan apa yang menjadi kebutuhan dari kelompok tani Kalelon untuk Pengembangan kelompok tani pada umumnya.

\section{DAFTAR PUSTAKA}

Amanah, Siti dan Farmayanti, Narni, 2014. Pemberdayaan Sosial Petani-Nelayan, Keunikan Agroekosistem dan Daya saing. Penerbit Yayasan Pustaka Obor Indonesia, Jakarta.

Anantanyu, S, 2009. Partisipasi Petani dalam Meningkatkan Kapasitas Kelembagaan Kelompok Petani (Kasus di Propinsi Jawa Tengah) Disertai pada Institut Pertanian Bogor. http:agribisnis.fp.uns.ac.idwp content/uploads/2013/10/05-Sapja Anantanyu-Kelembagaan-PetaniPeranDan-Strategi- Pengembangan-

Kapasitasnya.pdf (diakses pada 12 Juli 2016).

Aprilia, dkk, 2015. Pembangunan Berbasis Masyarakat. Penerbit Alfabeta. Bandung.

Hikmat, H., 2004. Strategi Pemberdayaan Masyarakat. Penerbit Humoniora, Bandung.

Khairuddin, 2000. Pembangunan Masyarakat, Tinjauan Aspek: Sosiologi, Ekonomi dan Perencanaan. Liberty, Yogyakarta.

Makeham, J.P. dan R.L. Malcom, 2001. Manajemen Usahatani Daerah Tropis. Jakarta: LP3ES.

Nuryanti dan Swastika, 2011. Peran Kelompok Tani dalam Penerapan Teknologi Pertanian.http://pse.litbang.deptan.go.idin d/pdffiles/FAE29-2d.pdf diakses pada 20 Juli 2016.

Peraturan Menteri Pertanian (Permentan) No. 273 Tahun 2007, Partisipasi Anggota Dan Kinerja Gabungan Kelompok Tani Agopurna Mitra Mandiri Di Kabupaten Bandung Barat Provinsi Jawa Barat. Skripsi Deni Koswara H34077009 Departemen Agribisnis Fakultas Ekonomi Dan Manajemen Institut Pertanian Bogor. Bogor 2011
Ramli, 2010. "Pentingnya Koordinasi, Integrasi, Sinkronisasi dan Sinergitas antar SKPD dalam Proses Implementasi Program Agropolitan dan Agromerinepolitan di Sumatera Utara". Pembangunan Perdesaan dalam Rangka Peningkatan Kesejahteraan Masyarakat. Pemikiran Guru Besar Perguruan Tinggi Badan Hukum Milik Negara. Bogor:IPB Press.

Riduwan, 2012. Rumus dan Data Analisis Statistika. Penerbit Alphabet. Bandung.

Septiany, Irma. 2012. Parisipasi Masyarakat dalam Implementasi Program Nasional Pemberdayaan Masyarakat (PNPM) Mandiri Perkotaan dengan Penggunaan Model CLEAR di Kelurahan Kaliabang Tengah, Kecamatan Bekasi Utara, Kota Bekasi. Skripsi Jurusan Ilmu Administrasi Negara. Fakultas Sosial dan Ilmu politik. Universitas Indonesia. Depok

Soetriono, Anik Suwandari dan Rijanto, 2006. Pengantar Ilmu Pertanian. Malang: Bayumedia Publishing.

Sumardjo, M.A. Chozin dan Ali Khomzan, 2010. "Transformasi Perencanaan Pwmbangunan Perdesaan dengan Beragam Tipologi". Pembangunan Perdesaan dalam Rangka Peningkatan Kesejahteraan Masyarakat. Pemikiran Guru Besar Perguruan Tinggi Badan Hukum Milik Negara. Bogor: IPB Press.

Suswono, 2013. Administrasi Penyuluhan Pertanian Pada Kelompok Tani Di Kecamatan Tomohon Utara Kota Tomohon. Proposal Daisy Sumilat 120314065 Fakultas Pertanian. Universitas Sam Ratulangi Manado. Manado 2016

Uphoff, Norman Thomas, 2000. Local Institutional Development: An Anlytical Soucebook With Cases. Kumarian Press. http://agribisnis.fp.uns.ac.ad/ wp content/uploads/201310/05-SapjaAnantanyu-Kelembagaan-PetaniPeran-Dan-Strategi-PengembanganKapasitasnya.pdf. (Diakses pada 12 Agustus 2016). 